\title{
WALT WHITMAN, THE BACHELOR, AND SEXUAL POETICS
}

\author{
Matt Cohen
}

LATE IN 1849, Walter Whitman began writing a series of local color sketches for the New York Sunday Dispatch. To help the essays flow together and to provide a focus for narrative commentary, Whitman used a tactic that was familiar to his readers-he posed as a wandering bachelor. The resulting series, "Letters from a Travelling Bachelor," drew on conventions established by British essayists of the eighteenth century like Joseph Addison and Sir Richard Steele and further developed by Americans such as Washington Irving (in The Sketch Book and Tales of a Traveller, among others) and James Fenimore Cooper (in his 1828 Notions of the Americans: Picked Up by a Travelling Bachelor). This popular convention cast the bachelor as an urbane and rational, hence ideal, observer of society, uninhibited and unbiased by either the demands of physical labor or domestic responsibilities. If only for the power of the convention, the bachelor pose must have seemed ideal for Whitman's purpose of depicting a broad spectrum of the American people. ${ }^{1}$

Yet strangely, this was the last time Whitman used the bachelor pose in his work; even the word "bachelor" does not appear in his poetry, and extremely rarely in his other writing or records of his conversation. In 1844, Whitman began his short story "My Boys and Girls" with the words, "Though a bachelor, I have several girls and boys that I consider my own." His famous response to John Symonds of 1890 begins, "Tho' always unmarried I have had six children. ..." Why did he decide to avoid the concept - and the word? The facts of Whitman's reallife domestic bachelorhood complicate this inquiry and certainly make it more urgent. Because of the centrality of questions of both narrative authority and male sexuality to the study of Whitman, the issue of his discursive and his social bachelorhoods is close to the heart of recent critical debates. In this paper I will provide a brief sense of what Mikhail Bakhtin would call the "accent" of the word "bachelor" in Whitman's time. It is my hope that exploring how and why Whitman avoided the literary bachelor yet embraced a social one can help us rethink the relationships among cultural discourses-in this case social and literary ones-that seem to share gendered terms. 
The word "bachelor" originated in Europe around the fourteenth century as a military term, designating a knight without a banner. Several etymologies suggest that, in fact, the term "bachelor" comes from the French bas chevalier, or lesser knight. In English, the term emerged in academia to indicate a similar status for a student-one who had achieved the primary degree. This use seems to have become common by the fifteenth century and coexisted for a time with the residual chivalric sense of the term. As middle-class professionalism flourished and national boundaries were established, the academic designation of "bachelor" became the primary definition of the word throughout Europe. At both stages of the early evolution of the word, single marital status was implied, and at the later stages, in the sixteenth and seventeenth centuries, celibacy was implied, as it was generally required of students. (The French for "bachelor" is still célibataire.)

As higher education became both secularized and more essential to an international bourgeois commercial culture, "bachelor" came more generally to connote a comfortable, educated single male. By the eighteenth century, the word was being used by Addison and Steele to establish an ideal position within the public sphere. Physical latitude explains why this spectator was explicitly gendered male-unlike women, men could freely wander the city and cast their gazes on most objects without risking their reputations. ${ }^{3}$ With this freedom, and unburdened by the demands of marriage, the educated single man could best represent the interests of the nation. This connotation-and the ideal of masculine intellectual production as necessarily isolated from enervating female influences-lingered on in nineteenth-century American literary culture. "The great men are all bachelors, you know," we are told in Herman Melville's Pierre, or, the Ambiguities, while Margaret Fuller reported Ralph Waldo Emerson as saying of marriage, "Ask any woman whether her aim in this union is to further the genius of her husband, and she will say yes, but her conduct will always be to claim a devotion day by day that will be injurious to him, if he yields." ${ }^{5}$ Whitman used this pose in "Letters from a Travelling Bachelor," explicitly mentioning the theory at one point:

Now that old Dutch Dr. Zimmermann, who wrote so profoundly and acted so foolishly, commends "solitude" as the greatest developer and establisher of virtuous conduct, and intellectual and scientific improvement. Also, it is a common way among writers to speak in the same strain-to make much of "the soothing pleasures of retirement," and the "calm delights of obscurity."

Yet at the same time, in popular literature, "bachelor" came to connote a strain of essentially pornographic literature, including for example The Bachelor's Pocket Book for 1851, a list of whorehouses and private prostitutes-a resource one could find for most large cities. ${ }^{7}$ 
Closer to Whitman's experience (perhaps) was an 1864 circular advertising lewd "New Pictures for Bachelors," which so enraged Captain M. G. Tousley that he sent a copy of it with a letter directly to Abraham Lincoln. ${ }^{8}$

The illicit implication of the word "bachelor" had its counterpart in proscriptive literature and social reform movements of the early nineteenth century. Whitman himself in his early journalism once criticized "single fools, the bachelors and maids who are old enough to be married-but who from appearances, will probably 'die and give no sign,"” recommending, in harmony with Parson Weems, William Alcott, and other moralists, "Young man reader! if you have good health, are over twenty-one years old, and nothing to 'incumber' you, go and get married." $"$

Given Whitman's statement that he wanted to "keep in mind the difference between the simply erotic, the merely lascivious, and what is frank, free, modern, in sexual behavior" and what David Reynolds calls Whitman's "distaste for habitual obscenity," the negative connotations of the bachelor character and pose may in small part help explain Whitman's decision not to utilize it. ${ }^{10}$ But more significantly, Whitman rejected these terms because he wanted to talk about sexuality in a new way-to dissociate it both from the stratosphere of the archaically celibate intellectual discourse and also from the predominantly genital motives of pornography. Adopted by so many of Whitman's contemporaries, from Hawthorne to N. P. Willis to Donald Grant Mitchell, the bachelor pose both gendered authority as masculine and reinscribed social boundaries of class, education, race, and nationality. ${ }^{11}$ For Whitman this trope was too limiting; his view of how gender should function in his poetry was very different.

A characteristic example comes from the poem "Walt Whitman" in the 1871-72 Leaves of Grass. In the space of three line-groups, we get a full spectrum of possible masculinities for the narrator.

\section{8}

I am he attesting sympathy;

(Shall I make my list of things in the house, and skip the house that supports them?)

119

I am not the poet of goodness only-I do not decline to be the poet of wickedness also.

120

Washes and razors for foofoos-for me freckles and a bristling beard. ${ }^{12}$

First the poet voices the sentimental observer; his specific insistence on a "he" attesting sympathy who lists domestic objects spites the convention that sympathy was a female trait. ${ }^{13}$ The next image, of the poet of 
wickedness, evokes the masculine litterateur's objectivity and heroic confrontation with the dark side of human nature. Finally, the last voice, denigrating "foofoos," seems to reject both its predecessors with an unshaved, befreckled-because-outdoors, muscular, masculine man.

The synthesis of ideal sympathy and muscularity in this passage emblematizes Whitman's larger project of joining what he calls “adhesiveness" or "the passion of friendship for man" with political democracy. This amalgam has been discussed by Robert K. Martin, M. Jimmie Killingsworth, and several others; as Betsy Erkkila has stated it, "By conceptualizing and articulating his love for men in the language of democratic comradeship and by celebrating physical pleasure among men in the context of male and female amativeness and procreation, Whitman in fact suggests the extent to which the bounds between private and public, male and female, heterosexual and homosexual, are still indistinct, permeable, and fluid in his work." 14 The conventional, literary bachelor pose was both unable to transgress these boundaries and ineffective at provoking readers to rethink the relationships among gender, politics, and poetics. In Robert Davis's words, it could not defy "social and linguistic fixity" because it relied on hierarchies for its effectiveness. ${ }^{15}$

But following the social logic of Whitman's insistence on adhesiveness, the kind of close, public masculine companionship he demands seems almost to require single marital status. Certainly Whitman's own life was a powerful example of fellowship for his followers, and he himself declared to Richard Maurice Bucke, "I suppose the chief reason why I never married must have been an overmastering passion for entire freedom, unconstraint; I had an instinct against forming ties that would bind me." 16 This "passionate" domestic bachelorhood itself made a political statement during his time. Cultural scholars and historians from Carroll Smith-Rosenberg to Howard Chudacoff have recently argued that, in Vincent Bertolini's words, "though the bachelor was a fact of the American social scene, he represented one of the worst threats to nineteenth-century bourgeois social and sexual ideology." ${ }^{17}$ In the light of recent work by George Chauncey, for example, who suggests in Gay New York that the word "bachelor" became in urban New York a code word for "gay" by the 1890s, Whitman might be said to have used his social bachelorhood itself transgressively, as a kind of code for his sexual preferences. ${ }^{18}$ Thus, when late in life he qualified Horace Traubel's comments about his solitary life by saying that he was "Not too much of a bachelor, either, if you knew it all!," Whitman's concluding chuckle may have been at the expense of Traubel, who claims to have been expecting to hear about a clearly heterosexual secret from the poet's past. ${ }^{19}$ That this comment is difficult for Traubel to interpret is telling; Whitman here plays with the gap between his literary and his real-life 
bachelorhoods. His awareness of the multifarious connotations of the bachelor in different discursive realms exemplifies the fluidity he advocated between literature and society.

The sequestering of the bachelor persona evidenced in Whitman's writing and his life finds a kind of analogue in what Ed Folsom describes as the "obscurity and encrypted quality" of photographs of Whitman and his male companions. As they are simultaneously self-consciously constructed images and material evidence of Whitman's life, these pictures are suggestive about the poet's understanding of the single life. ${ }^{20}$

With the "family pictures," like his photographs with the Johnston and Williams families' children, Whitman used his bachelorhood to promote his image as a family man-a father, or more often in the photographs, grandfather figure. In these photographs, Whitman is always touching or holding the children-partly to keep them from fidgeting, a common tactic in nineteenth-century photography-and he is always looking at the camera. His status as an older single male enables, in Folsom's words, an image using "the conventions of a posed family portrait where the 'family' has to be construed outside traditional definitions, even while familiar and comforting 'family' emotions are triggered by the careful staging and posing." 21 In this case, then, Whitman used his old bachelor status to pose as a family man.

But the case was different in his photographs with boyfriends, young men like Peter Doyle and Bill Duckett. Folsom suggests that in these photographs Whitman "cross-pose[d]," using "traditional wedding postures"; "gender and sex and even generation lose their categorical status as Whitman and his comrades stage unnamed identities and relationships." 22 Yet in these images Whitman keeps his hands to himself; his partners usually (but not always) lay one hand on him, but we hardly see the affectionate embrace of comrades. In the pictures with Doyle, in fact, Whitman's hands are completely obscured, either in his pockets or crossed under his arms. Furthermore, while Whitman may have been experimenting with new ways of picturing adhesiveness, his maintenance of bachelorhood as a personal lifestyle based on complete unrestraint and domestic latitude suggests that "marriage" would not have been an adequate model for homosexual relationships.

We know that Whitman resisted objectification in his use of these photographs, sharing them with friends but discouraging their reproduction. Very much like his bachelorhood, then, Whitman carefully controlled the circulation of these images-and for more or less the same reasons. For just as the word "bachelor" was easily robbed of evocative power by its literary contexts, so public circulation of the "Calamus" photos would simultaneously remove the emotional investment 
Whitman made in them and tame them with a heterosexual interpretation.

Whitman's negotiation of bachelorhood-avoiding it in print and embracing it in his persona-demonstrates the complexity we face in reconstructing concepts like "bachelorhood" from our own times, when the word has lost much of its resonance. As V. N. Voloshinov put it in 1930, "A sign that has been withdrawn from the pressures of the social struggle - which, so to speak, crosses beyond the pale of class struggleinevitably loses force, degenerating into allegory and becoming the object not of live social intelligibility but of philological comprehension. The historical memory of mankind is full of such worn out ideological signs incapable of serving as arenas for the clash of live social accents." ${ }^{23}$ Whitman's relationship with the word "bachelor" suggests the possibility that at times, words are also avoided because of the struggle being staged through them. Whitman himself argued in An American Primer that "The lack of any words . . . is as historical as the existence of words." But just as he went on to say, "I feel a hundred realities, clearly determined in me, that words are not yet formed to represent," so he eschewed those words that bore cultural significance clearly detrimental to the interpretation of his poetry-especially in this case to the central argument about sexuality, manhood, and democracy. ${ }^{24}$ In March of 1890 , the same year Symonds posed his famous inquiry, Maurice M. Minton of the magazine Illustrated American requested of Whitman a few lines of text to accompany a picture of the poet as a frontispiece. Whitman happily obliged, sending a few lines from section sixteen of "Song of Myself." A month later, Minton asked the poet to answer a different inquiry-this time, "Why am I a bachelor?" Whitman apparently made no answer to the query. ${ }^{25}$ This reticence, paradoxically, speaks to us, showing Whitman's powerful awareness of American print culture and its connotations. Yet it also shows the ways in which a concept that has lost much of its controversial aura with the successive sexual revolutions of the twentieth century once had a multifarious and controversial life in divergent cultural arenas.

\section{The College of William and Mary}

\section{NOTES}

1 New York Sunday Dispatch, October 14, 1849 - January 6, 1850. This essay uses the reprint in Joseph Jay Rubin, The Historic Whitman (University Park, Pennsylvania: Pennsylvania State University Press, 1973), 311-354. Washington Irving, The Sketch Book of Geoffrey Crayon, Gent. (1820; rpt. New York: Signet, 1961).

2 Walt Whitman, "My Boys and Girls," in The Early Poems and Fiction, ed. Thomas L. Brasher (New York: New York University Press, 1963), 248; Whitman, The Correspondence, ed. Edwin Haviland Miller, Vol. 5: 1890-1892 (New York: New York University Press, 1969), 73. Emphasis added. 
3 The bachelor and what has come to be known as the flaneur share some ground as masculine observers; see Dana Brand, The Spectator and the City in Nineteenth-Century American Literature (New York: Cambridge University Press, 1991). Wyn Kelley, on the other hand, argues that the category of the flaneur does not apply in the American context, and certainly in Whitman's case the wandering observer does not rely exclusively on the city or the crowd in the way the flaneur does. Kelley, Melville's City: Literary and Urban Form in Nineteenth-Century New York (New York: Cambridge University Press, 1996).

4 An expanded version of this brief history of "bachelor" with full citations can be found in my dissertation-in-progress, "The Still Life: Bachelors and Masculine Subjectivity in Nineteenth-Century America," The College of William and Mary.

5 Herman Melville, Pierre, or, the Ambiguities (1852, rpt. New York: Signet, 1964); Fuller quoted in Carlos Baker, Emerson Among the Eccentrics: A Group Portrait (New York: Viking, 1996), 193.

6 Whitman quoted in Rubin, 318.

7 See Michael Slater, "The Bachelor's Pocket Book for 1851," Sexuality in Victorian Literature, ed. Don Richard Cox (Knoxville: University of Tennessee Press, 1984), 128-140.

8 John D'Emilio and Estelle B. Freedman, Intimate Matters: A History of Sexuality in America (New York: Harper \& Row, 1988), 132.

9 Whitman quoted in David Reynolds, Walt Whitman's America: A Cultural Biography (New York: Knopf, 1995), 223. Though Reynolds here suggests that Whitman "venerated the marriage institution" throughout his life, the kind of pro-marriage vehemence reflected in this quote does not appear in his later writings. For a concise topography of antebellum medico-moralist literature, see D'Emilio and Freedman, 67-72.

10 Whitman quoted in Reynolds, 203; Reynolds, 203.

11 Hawthorne, The Blithedale Romance (1852) especially and lk Marvel [Donald Grant Mitchell], The Reveries of a Bachelor (1850; rpt. Philadelphia: Altemus, 1893). Mitchell's book was reprinted frequently during the nineteenth century, testifying to the continuing appeal of the bachelor theme. See Katherine Victoria Snyder, "Bachelor Narrative: Gender and Representation in Anglo-American Fiction, 1850-1914" (Ph.D. Diss., Yale, 1991,) for an extensive yet only partial bibliography of bachelor sources from the nineteenth century.

12 Walt Whitman, Leaves of Grass (Washington, D.C.: Redfield, 1871-1872), 52.

13 See recent work on sympathy and American literature by Elizabeth Barnes, States of Sympathy: Seduction and Democracy in the American Novel (New York: Columbia University Press, 1997) and Julia A. Stern, The Plight of Feeling: Sympathy and Dissent in the Early American Novel (Chicago: University of Chicago Press, 1997).

14 Betsy Erkkila, "Whitman and the Homosexual Republic," Walt Whitman: The Centennial Essays, ed. Ed Folsom (Iowa City: University of Iowa Press, 1994), 162; M. Jimmie Killingsworth, Whitman's Poetry of the Body: Sexuality, Politics, and the Text (Chapel Hill: University of North Carolina Press, 1989); Robert K. Martin, "Whitman's Song of Myself: Homosexual Dream and Vision," Partisan Review 42 (1975), among many others.

15 Robert L. Davis, Whitman and the Romance of Medicine (Berkeley: University of California Press, 1997), 64. 
16 Richard Maurice Bucke, Walt Whitman (Philadelphia: David McKay, 1883), 60.

17 Vincent J. Bertolini, "Fireside Chastity: The Erotics of Sentimental Bachelorhood in the 1850s," American Literature 68 (December 1996), 707-737; 708-709; Howard Chudacoff, The Age of the Bachelor: Creating an American Subculture (Princeton, NJ: Princeton University Press, 1999); Carroll Smith-Rosenberg, Disorderly Conduct: Visions of Gender in Victorian America (New York: Knopf, 1985).

18 See George Chauncey's Chapter 5, "Urban Culture and the Policing of the 'City of Bachelors," in Gay New York: Gender, Urban Culture, and the Making of the Gay Male World, 1890-1940 (New York: Basic Books, 1994).

19 Traubel quoted in Gary Schmidgall, Walt Whitman: A Gay Life (New York: Dutton, 1997), xvi.

20 Ed Folsom, "Whitman's Calamus Photographs," Breaking Bounds: Whitman and American Cultural Studies, ed. Betsy Erkkila and Jay Grossman (New York: Oxford University Press, 1996), 206.

21 Folsom (1996), 196.

22 Folsom (1996), 205.

23 V. N. Volosinov, Marxism and the Philosophy of Language, trans. Ladislav Matejka and I. R. Titunik (New York, Seminar Press, 1973), 23.

24 Walt Whitman, An American Primer, ed. Horace Traubel (1904; rpt. Stevens Point, Wisconsin: Holy Cow! Press, 1987), 21.

25 Illustrated American April 19, 1890, request March 9; second inquiry April 2, 1890; whole story, Whitman, Early Poems and Fiction, 548 n.3012. 